\title{
Pengaruh Model Group Investigation dengan Metode Problem Solving Terhadap Kemampuan Berpikir Kritis Peserta Didik Kelas XI IPS SMAN 1 Bangil
}

\author{
Abdurrahman Wahid \\ Program Studi Pendidikan Ekonomi, Fakultas Ekonomi, Universitas Negeri Surabaya \\ e-mail : abdurrahmanwahid@mhs.unesa.ac.id
}

\begin{abstract}
Abstrak
Tujuan penelitian ini yaitu untuk mengetahui pengaruh model pembelajaran Group Investigation dengan metode Problem Solving terhadap kemampuan berpikir kritis peserta didik kelas XI IPS SMAN 1 Bangil. Jenis penelitian yang digunakan adalah eksperimen semu dengan nonequivalent control group design. Subyek dalam penelitian ini menggunakan kelas XI IPS 2 dan XI IPS 3 SMAN 1 Bangil. Teknik penelitian data yang digunakan adalah tes pilihan ganda guna mengukur kemampuan berpikir kritis peserta didik lalu data yang diperoleh dianalisis dengan uji T (Mann Whiteney test). Hasil penelitian menunjukkan bahwa model pembelajaran Group Investigation dengan metode Problem Solving mempunyai pengaruh signifikan terhadap kemampuan berpikir kritis peserta didik yang dibuktikan oleh perolehan uji $\mathrm{t}$ dengan taraf signifikansi $0,028<0,05$. Sehingga disimpulkan bahwa model pembelajaran Group Investigation dengan metode Problem Solving memiliki pengaruh terhadap kemampuan berpikir kritis peserta didik kelas XI IPS SMAN 1 Bangil dan kelas eksperimen memiliki kemampuan berpikir kritis lebih tinggi dari kelas kontrol yang dibuktikan dengan peringkat rata-rata (mean rank) kelas eksperimen sebesar 34,57 dan kelas kontrol sebesar 25,28.
\end{abstract}

Kata Kunci: Group investigation, Problem solving, Kemampuan Berpikir Kritis

\section{Abstract}

The purpose of this study is to know the influence of Group Investigation model learning and Problem Solving method towards critical thinking skill of social study students grade XI of SMAN 1 Bangil. The type of this study is a quasi-experimental design with nonequivalent control group design. The subjects of this research are social study students grade XI 2 and social study students grade XI 3 SMAN 1 Bangil. The research of data technique used in this study is multiple choice test to measure students' critical thinking skill and then the collected data is analyzed by T-test (Mann Whiteney test). The result of this study shows that Group Investigation model learning and Problem Solving method had an influence on students' critical thinking skill which is proved by T-test result with significance level $0,028>0,05$. So it can be concluded that Group Investigation model learning and Problem Solving method had an influence on students' critical thinking skill social study students grade XI 2 and social study students grade XI 3 SMAN 1 Bangil and the experiment class has critical thinking skills higher than the control class proved by mean rank of experiment class 34,57 and control class 25,28.

Keywords: Group investigation, Problem solving, Critical thinking skill

\section{PENDAHULUAN}

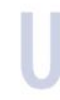

Pendidikan merupakan sebuah tolak ukur peradaban suatu bangsa dan kualitas sumber daya manusia dapat dibentuk melalui pendidikan. Perkembangan ilmu pengetahuan dan teknologi yang maju di era global dimana informasi dengan dapat mudah tersebar. Di sisi lain, pada era keterbukaan informasi, membuat masyarakat khususnya peserta didik berpotensi untuk dikendalikan oleh arus informasi, hal ini dibuktikan dengan penelitian oleh Eka, (2018) yang menunjukkan bahwa dari $75 \%$ responden yang diantaranya 14,52\% adalah usia 16 - 19 tahun menyatakan sulit untuk mendeteksi hoax atau informasi bohong. Hal ini rawan untuk membenarkan semua informasi tanpa klarifikasi dari media massa maupun berbagai media lainnya. Untuk menghadapinya, Maka keterampilan yang harus menjadi fokus utama untuk dikembangkan pada proses pembelajaran di sekolah adalah keterampilan berpikir kritis sehingga peserta didik mampu untuk mengkonstruksi pengetahuan dan pengamatannya. Sejalan dengan perkembangan zaman yang memasuki era abad 21 dimana seseorang dituntut untuk memiliki berbagai keterampilan hidup agar dapat bersaing dan berkolaborasi di era global (Zubaidah, 2016).

Dalam perkembangan pembelajaran era abad 21, kemampuan berpikir kritis perlu diperhatikan lebih lanjut, sebab fenomena yang masih terjadi yaitu rendahnya 
kemampuan berpikir kritis peserta didik. Hal tersebut dibuktikan dengan penelitian oleh Priyadi, Mustajab, Tatsar, \& Kusairi (2018) bahwa 56\% peserta didik dapat menyelesaikan perhitungan fisika. Namun, kesulitan peserta didik terletak pada saat memaknai data yang diberikan. Artinya peserta didik hanya mencapai keterampilan berpikir tingkat $\mathrm{C} 1$ hingga $\mathrm{C} 2$. Dan penelitian oleh Nelson \& Crow (2014) bahwa 65\% hingga $80 \%$ dari akademisi menghabiskan waktu kelas mereka untuk mengajar kepada peserta didik yang pasif dengan sedikit atau tanpa fokus pada pengembangan kelompok, pembelajaran aktif dan mengembangkan keterampilan pemecahan masalah. National Research Council (dalam Nelson \& Crow, 2014) menjelaskan faktor yang menjadi sebabnya fenomena tersebut salah satunya yaitu dalam kegiatan belajar dan mengajar masih menerapkan pembelajaran langsung atau ceramah sebagai metode menyampaikan pelajaran.

Dari hasil observasi peneliti ditemukan fakta bahwa pembelajaran dapat berjalan dengan optimal jika peserta didik terlibat dalam proses pembelajaran secara aktif, namun peserta didik lebih cenderung pasif seperti saat dilakukan diskusi hanya sebagian kecil peserta didik yang berperan di dalamnya, bahkan beberapa peserta didik beberapa kali terlihat sibuk dengan urusan di luar proses pembelajaran seperti berbincang diluar topik pelajaran dengan temannya, selain itu peserta didik jarang mengemukakan pertanyaan maupun pendapat saat proses tanya jawab dan diskusi bersama. Hal tersebut dapat dilihat saat guru memberikan kesempatan bertanya dan berpendapat namun hanya peserta didik tertentu saja yang mampu mengemukakan pertanyaan dan pendapat, selain itu peserta didik cenderung memberikan jawaban yang sama dan belum dapat memberikan alternatif jawaban penyelesaian masalah, sehingga peserta didik pada umumnya hanya mencapai ranah kognitif $\mathrm{C} 1$ sampai dengan $\mathrm{C} 2$.

Upaya yang bisa diterapkan untuk mengembangkan kecakapan siswa dalam berpikir kritis yaitu perlu adanya inovasi pada model maupun metode pembelajaran. Menurut Arends (dalam Fathurrohman, 2015, p. 30) Model pembelajaran adalah persiapan rangkaian rencana tahap pembelajaran untuk mengelola kegiatan belajar peserta didik baik ilmu pengetahuan, sikap dan keterampilan. Sehingga melalui model pembelajaran guru dapat mengelola kegiatan belajar dengan mengutamakan kegiatan peserta didik. dengan begitu peserta didik dapat mengembangkan keterampilan berpikirnya. Hal tersebut didukung dengan pernyataan Konfucius (dalam Amri, 2015, p. 34) diantaranya: 1) Apa yang saya dengar, saya lupa 2) Apa yang saya lihat, saya ingat 3) Apa yang saya lakukan, saya paham.
Pembelajaran Investigasi kelompok dikembangkan oleh Shlomo Sharan dan Yael Sharan pada tahun 1992, Model pembelajaran GI didefinisikan rencana organisasi kelas umum dimana peserta didik dibagi kedalam kelompok-kelompok kecil lalu melakukan kegiatan penyelidikan, diskusi dan perencanaan serta proyek koperasi (Li \& Lam, 2013). Selain itu, model kooperatif ini dikatakan sebagai salah satu strategi pembelajaran yang lebih mengutamakan keterlibatan peserta didik sehingga mereka memiliki banyak kebebasan dalam memilih topik yang mereka minati untuk diselidiki, merencanakan dan melaksanakannya, menyajikan dan mengevaluasi hasilnya. Model pembelajaran ini dapat mendorong untuk mengembangkan kemampuan berpikir secara kritis dan mandiri (Fathurrohman, 2015, p. 69). Hal tersebut didukung oleh penelitian Adiansyah, Muh.Amin, Mansyur, \& Mu'nisa (2017) bahwa model Group Investigation mampu menumbuhkan keaktifan dan tanggung jawab peserta didik ketika kegiatan pembelajaran dan mampu membuat penyelesaian masalah sehingga peserta didik dapat meningkatkan keterampilan berpikir mereka.

Implementasi model pembelajaran didalamnya juga terdapat metode pembelajaran. Upaya membangun kemampuan berpikir kritis juga dapat didukung melalui metode pembelajaran Problem Solving. Problem Solving merupakan strategi belajar dan mengajar dengan cara peserta didik dihadapkan pada berbagai permasalahan untuk dipecahkan sendiri atau dengan berkelompok (Riandani, 2012). Penerapan pembelajaran pemecahan masalah juga diperkuat oleh penelitian oleh Utami, Saputro, Ashadi, Masykuri, \& Sutanto (2017) bahwa hasil penelitian menunjukkan penerapan Pemecahan Masalah (Problem Solving) dalam kegiatan belajar para peserta didik dituntut untuk secara aktif berdiskusi dan berkolaborasi sesama anggota kelompok untuk menemukan solusi terhadap masalah yang diberikan sehingga dapat menumbuhkan keterampilan berpikir kritis dan prestasi belajar peserta didik. Serta didukung hasil penelitian oleh Apriani (2017) menunjukkan peserta didik menggali pengetahuan yang mereka miliki kemudian mengembangkan keterampilan berpikir mereka menjadi lebih kritis selain itu dengan terbiasa mereka menyelesaikan permasalahan akan memunculkan ide baru mereka atau inovasi baru mereka tentang permaslahan yang mereka hadapi nantinya.

Sesuai dengan penjelasan diatas maka model yang tepat agar kecakapan berpikir kritis siswa dapat meningkat adalah dengan strategi kelompok investigasi dengan metode pemecahan masalah, karena melalui model dengan metode tersebut peserta didik melaksanakan berbagai kegiatan belajar seperti, 
menjelaskan dan mengemukakan sesuatu yang berasal dari pemikiran mereka sendiri, bersifat terbuka dengan pemikiran individu lain, menumbuhkan tanggung jawab dalam belajar, meningkatkan prestasi peserta didik, menganalisa informasi dan permasalahan dengan akurat, serta mampu memecahkan permasalahan.

Model Group Investigation didefinisikan rencana organisasi kelas umum dimana peserta didik dibagi kedalam kelompok-kelompok kecil lalu melakukan kegiatan penyelidikan, diskusi dan perencanaan serta proyek koperasi (Li \& Lam, 2013). Sedangkan menurut Hamdani (dalam Apriani, 2017) metode Problem Solving atau pemecahan masalah merupakan cara menyampaikan pelajaran kegiatan mencari dan memecahkan suatu masalah agar tercapainya tujuan belajar. Fungsi guru ialah memberi memotivasi peserta didik untuk tertantang dan memiliki keinginan kuat untuk memcahkan masalah yang terjadi. Maka Model Group Investigation dengan metode Problem Solving diartikan sebagai strategi pembelajaran dengan cara kooperatif dimana kelas dibagi dalam beberapa kelompok 3-5 orang, kelompok yang telah terbentuk mengkaji salah satu subtopik, lalu dihadapkan pada suatu permasalahan untuk dipecahkan dan dipresentasikan kepada seluruh kelas. Dengan diterapkannya Model Group Investigation dengan metode Problem Solving peserta didik dapat dengan leluasa menemukan informasi atau materi dengan sumber daya yang ada, mengkontruksi pengetahuannya serta menemukan jawaban dari hasil investigasi dan penyelesaian masalah melalui pengamatannya sendiri.

Berpikir kritis menurut Edward Glaser (dalam Fisher, 2007, p. 3) mengartikan berpikir kritis sebagai (1) kemauan sikap berpikir terhadap berbagai masalah dengan teliti dan dalam capaian pengalaman seseorang; (2) kepandaian dalam berbagai teknik penyelidikan dan pemikiran yang masuk akal; dan (3) kemampuan mengimplementasikan berbagai teknik tersebut. Berpikir secara kritis mansyaratkan usaha yang lebih untuk menguji setiap prinsip atau pengetahuan asumtif yang berdasar pada bukti yang mendukung. Menurut Norris dan Ennis (dalam Yoke, Jangga, \& Kamal, 2015) mendeskripsikan berpikir kritis yaitu cara berpikir yang reflektif dan logis agar dapat menyimpulkan tentang sesuatu yang seharusnya diyakini maupun diterapkan. Adapun indikator berpikir kritis menurut Ennis (dalam Rahmawati, 2011) yakni : (1) Membuat Penjabaran dasar (2) Membangun Keterampilan dasar (3) Menyimpulkan (4) Memaparkan penjelasan lanjut (5) Membuat strategi dan taktik

Dari latar belakang diatas, maka tujuan dalam penelitian ini yaitu untuk menganalisis pengaruh model pembelajaran Group Investigation dengan Metode
Problem Solving Terhadap Kemampuan Berpikir Kritis kelas XI IPS SMAN 1 Bangil.

\section{METODE}

Rancangan penelitian ini menggunakan pretest sebagai langkah awal untuk mengetahui kemampuan dan kesiapan peserta didik dalam memulai pelajaran. Setelah peserta didik melaksanakan pretest, subyek penelitian terbagi menjadi 2 kelas yakni kelas dengan perlakuan Group Investigation dengan metode Problem Solving sedangkan pada kelas kontrol diberikan perlakuan model pembelajaran Group Investigation. Setelah diberikan perlakuan pada kelas kontrol dan eksperimen, peserta didik akan diberikan tes kembali yaitu berupa post-test untuk mengukur perbedaan setelah diberikan perlakuan dari model pembelajaran yang digunakan. Adapun bagan rancangan penelitian ditunjukkan pada gambar 1 berikut ini :

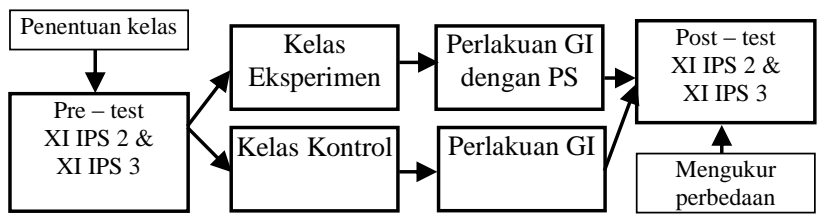

Gambar 1. Bagan Rancangan Penelitian

Sumber : Diolah oleh Peneliti (2019)

Rancangan penelitian yang digunakan yaitu Quasi Experimen dengan tipe Nonequivalent Control Group Design. Menurut Sugiyono (2010, p. 75) Quasi Experimental Design merupakan jenis desain penelitian yang didalamnya terdapat kelompok kontrol dan eksperimen yang tidak dipilih secara random.

Tabel 1. Rancangan Nonequivalent Kontrol Group

\begin{tabular}{lccc}
\hline Kelas & $\begin{array}{c}\text { Pre- } \\
\text { Test }\end{array}$ & Treatment & $\begin{array}{c}\text { Post- } \\
\text { Test }\end{array}$ \\
\hline Eksperimen & $0_{1}$ & $\mathrm{x}$ & $0_{2}$ \\
\hline Kontrol & $0_{3}$ & - & $0_{4}$ \\
\hline
\end{tabular}

Sumber: Sugiyono (2010, p. 76)

Keterangan:

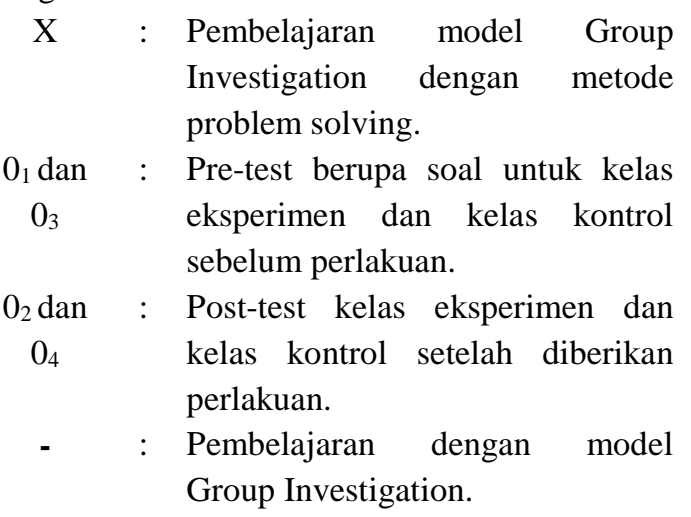

Subjek penelitian dalam penelitian ini merupakan kelas XI IPS 3 yang tediri dari 30 peserta didik sebagai kelas eksperimen dan kelas IPS 2 yang 
terdiri dari 29 peserta didik sebagai kelas kontrol. Pemilihan kedua kelas tersebut dipilih berdasarkan kemampuan akademik yang relatif sama. Kemampuan akademik dilihat dari nilai uji pre-test pada kedua kelas sampel. Data yang dikumpulkan dalam penelitian ini menggunakan metode tes diantaranya pre-test dan posttest, serta observasi dengan kegiatan pengamatan secara langsung dan cermat di lokasi penelitian untuk mengetahui kondisi yang terjadi.

Pada penelitian ini, peneliti menggunakan teknik analisis data menggunakan perangkat lunak SPSS yang dianalisis dengan uji Man Whiteney. Uji Mann Whiteney berfungsi untuk mengetahui ada tidaknya perbedaan ratarata data dua sampel. Uji beda non-parametrik ini digunakan apabila data tidak terdistribusi normal.

\section{HASIL DAN PEMBAHASAN}

Pada saat pembelajaran berlangsung, kegiatan pembelajaran yang dilakukan peneliti sesuai dengan RPP yang telah dirancang yang kemudian dinilai oleh observer dengan menggunakan lembar keterlaksanaan pembelajaran untuk menilai apakah KBM yang telah dilaksanakan oleh peneliti sesuai dengan sintaks model pembelajaran Group Investigation dengan metode Problem Solving. Uji hipotesis menggunakan uji Man Whiteney, namun sebelumnya perlu dilakukan uji normalitas, homogenitas dan uji beda untuk menentukan kelas Eksperimen dan Kontrol. Berdasarkan hasil output analisis data pre-test melalui perangkat lunak SPSS diperoleh uji normalitas sebesar 0,200 sehingga 0,200 > 0,05 , dari uji Normalitas tersebut maka disimpulkan data tersebut terdistribusi normal. Dari hasil uji homogenitas yang dianalisis dengan uji levene statistic dengan taraf siginifikan 0,596 sehingga nilai yang diperoleh lebih besar dari 0,05. Maka data yang diperoleh disimpulkan mempunyai kemampuan yang relatif sama atau homogen. hasil uji t-test for equality of means dengan taraf siginifikan 0,348. Sehingga data yang diperoleh lebih besar 0,05. Maka nilai tersebut dapat dikatakan 2 kelas memiliki kemampuan yang sama. Dari analisis data tersebut maka dapat ditentukan kelas Eksperimen dan kelas Kontrol.

\section{Pengaruh Model Group Investigation dengan metode Problem Solving terhadap kemampuan berpikir kritis Penulisan Daftar Pustaka}

Berdasarkan data yang diperoleh melalui uji beda Mann Whiteney ditunjukkan dengan taraf siginifikan 0,028 sehingga data yang diperoleh memiliki signifikansi lebih kecil dari 0,05. Maka disimpulkan dari kedua kelas tersebut mempunyai perbedaan signifikan. Selain itu, terdapat perbedaan nilai peringkat rata-rata Post-Test antara kelas Eksperimen dan kelas Kontrol. Nilai peringkat rata-rata Post-Test kelas Eksperimen sebesar 34,57 sedangkan kelas kontrol sebesar 25,28. Hal tersebut berarti peringkat rata-rata Berpikir Kritis Ekonomi peserta didik kelas Eksperimen lebih tinggi daripada kelas Kontrol. Dan dalam mengukur kemampuan berpikir kritis peserta didik dibuktikan dengan sebaran data ketuntasan soal berpikir kritis pada butir soal nomor 8, 9 dan 10 yang menggunakan soal dengan karakteristik analitis, dari hasil output persentase sebaran data ketuntasan soal berpikir kritis menunjukkan kelas eksperimen terjadi peningkatan signifikan daripada kelas kontrol. Pada kelas eksperimen terjadi peningkatan $27 \%$ pada butir soal nomor $8,10 \%$ pada butir soal nomor 9 dan $24 \%$ pada butir soal nomor 10 , sedangkan peningkatan pada kelas kontrol hanya pada butir soal nomor 8 dan 10 yaitu sebesar $14 \%$ dan tidak terjadi peningkatan pada butir soal nomor 9. Maka kedua kelas tersebut disimpulkan memiliki perbedaan kemampuan berpikir kritis. Perbedaan kedua perlakuan tersebut terletak pada perlakuan kelas eksperimen yang diberikan Model Group Investigation yang dikombinasikan dengan metode Problem Solving dimana peserta didik berperan aktif dalam kegiatan belajar, antara lain; Perencanaan pembelajaran, mengumpulkan informasi atau materi, kegiatan diskusi, saling bertukar pikiran dan ide-ide yang dimiliki antar anggota kelompok untuk menemukan penyelesaian masalah yang telah diskusikan. Sehingga dari kegiatan tersebut peserta didik dapat meningkatkan kapasitas berpikir kritisnya. Hal tersebut sejalan dengan teori dari Slavin (1995) bahwa strategi pembelajaran kooperatif dapat menciptakan kondisi pembelajaran yang mendorong keterampilan berpikir kritis untuk memecahkan masalah kompleks bernuansa kolaboratif. Dan sejalan dengan pernyataan Vigotsky (dalam Rusman, 2010, p. 244) bahwa pertumbuhan intelektual dapat terjadi saat individu menghadapi pengalaman baru dan menantang serta ketika berupaya dalam memecahkan suatu permasalahan.

Tingginya kemampuan berpikir kritis pada kelas Eksperimen daripada kelas Kontrol disebabkan oleh penerapan model Group Investigation dengan metode Problem Solving yang melibatkan secara aktif peserta didik dalam kegiatan belajar dengan fasilitator dan bimbingan oleh Guru. Saat pembelajaran peserta didik mengkontruksi pengetahuannya secara aktif melalui proses mengumpulkan informasi akurat terkait dengan materi atau subtobik yang dipelajari melalui kegiatan diskusi dengan anggota kelompok sehingga terjadi interaksi aktif untuk membandingkan argumen ataupun pendapat antar anggota, setelah perolehan informasi peserta didik dihadapkan pada suatu permasalahan kompleks berbentuk video dan masing-masing kelompok berusaha mengidentifikasi sebab masalah sampai dengan penyelesaian masalah sehingga peserta didik tertantang 
dan berusaha menggali berbagai informasi dan mencapai penyelesaian masalah lalu kajian materi dan penyelesaian masalah tersebut dipresentasikan untuk didiskusikan lebih lanjut dengan kelompok lainnya serta dilaksanakan evaluasi. Dari tahapan tersebut kapasitas berpikir peserta didik mampu dikembangkan. Hal tersebut didukung dengan hasil penelitian oleh Wijayanti, Herlambang, \& Slamet (2013) bahwa Model Pembelajaran Group Investigation mengarahkan pemikiran peserta didik dalam menganalisis dan mencari penyelesaian suatu masalah sehingga dapat membangun keterampilan peserta didik untuk berpikir lebih kritis. Dan juga sejalan dengan hasil penelitian oleh Astuti, Handoyo, \& Mustofa (2014) bahwa dalam metode pembelajaran penyelesaian masalah peserta didik dilibatkan dalam proses pembelajaran secara aktif dan kreatif, diantaranya melalui proses diskusi, saling bertukar pikiran yang dimiliki antar anggota kelompok sehingga mampu membuat penyelesaian suatu permasalahan yang dikaji. Dengan strategi belajar tersebut peserta didik belajar dengan mandiri dan aktif serta mampu untuk mencari informasi penting yang akurat, membuat penyelesaian masalah lalu dengan sendirinya peserta didik membangun kemampuan berpikir kritisnya.

Dengan diterapkannya Model Group Investigation dengan metode Problem Solving peserta didik dapat dengan leluasa menemukan informasi atau materi dengan sumber daya yang ada, mengkontruksi pengetahuannya serta menemukan jawaban dari hasil investigasi dan penyelesaian masalah melalui pengamatannya sendiri. Peserta didik diberikan stimulus untuk melatih kemampuan berpikir kritis dengan mencari informasi akurat, pemecahan suatu permasalahan, menganalisis argumen dan dapat membuat kesimpulan yang tepat.

$\begin{array}{ccc}\text { Materi } & \text { Perdagangan } & \text { Internasional yang } \\ \text { digunakan dalam proses pembelajaran } & \text { Group }\end{array}$ Investigation dengan metode Problem Solving merupakan salah satu pemicu untuk pelaksanaan pembelajaran dimana peserta didik belajar menemukan informasi dan penyelesaian masalah sehingga peserta didik terlibat secara aktif dan juga mampu meningkatkan kemampuan berpikir kritis. Dengan begitu hasil tes pada kelas eksperimen lebih tinggi daripada kelas kontrol. Hal tersebut sesuai dengan pernyataan pernyataan Konfucius (dalam Amri, 2015, p. 34) diantaranya: 1) Apa yang saya dengar, saya lupa. 2) Apa yang saya lihat, saya ingat. 3) Apa yang saya lakukan, saya paham. Dan juga sejalan dengan teori Konstruktivisme sosial Vygotsky (dalam Rachmawati, 2018) yang menjelaskan kegiatan pembelajaran secara kolaboratif untuk menemukan penyelesaian masalah yang menyesuaikan arahan dan bimbingan dari guru selama pembelajaran sehingga peserta didik belajar secara maksimal.

\section{PENUTUP}

\section{Simpulan}

Dari hasil penelitian diatas, maka bisa diambil kesimpulan bahwa kelas eksperimen memiliki kemampuan berpikir kritis lebih tinggi daripada kelas kontrol. Peserta didik yang diberikan perlakuan Model Group Investigation dengan Metode Problem Solving lebih banyak mengalami peningkatan berpikir kritis. Sehingga dapat disimpulkan Model Group Investigation dengan metode Problem Solving berpengaruh terhadap kamampuan berpikir kritis peserta didik kelas XI IPS SMAN 1 Bangil

\section{Saran}

Adapun dari paparan hasil penelitian dan simpulan, maka peneliti memberikan masukan bahwa Model Group Investigation dengan metode Problem Solving dapat menjadi alternatif Guru Ekonomi sebagai penerapan strategi pembelajaran yang inovatif karena sebagian besar pembelajaran Ekonomi pada jenjang SMA memiliki karakteristik analisis studi kasus serta menuntut peserta didik untuk memiliki kamampuan berpikir kritis. Dalam implementasi Model Group Investigation dengan metode Problem Solving agar lebih memperhatikan alokasi waktu pada saat menerapkam Group Investigation dengan metode Problem Solving karena pembelajaran secara kolaboratif dan bernuansa pemecahan masalah membutuhkan pengelolaan waktu yang efisien dan tepat.

\section{DAFTAR PUSTAKA}

Adiansyah, R., Muh.Amin, A., Mansyur, \& Mu'nisa, A. (2017). The Effectiveness of Group Investigation And Scientific Approach. Conference Paper, (December). Retrieved from www.reasearchgate.net/publication/321446997

Amri, S. (2015). Implementasi Pembelajaran aktif dalam Kurikulum 2013. (E. K. Ersaeila, Ed.). Jakarta.

Apriani, A. (2017). Pengaruh Metode Problem Solving terhadap Keterampilan Berpikir Kritis Siswa pada mata pelajaran IPS Ekonomi di Kelas X SMAN 1 Pringgarata Tahun Pelajaran 2016/2017. Skripsi.

Astuti, W., Handoyo, B., \& Mustofa. (2014). Pengaruh Model Pembelajaran Problem Solving Terhadap Kemampuan Berpikir Kritis Siswa Kelas XI-IS MA Muhammadiyah 2 Paciran. Jurnal Pendidikan Geografi.

Eka, R. (2018). Hoax Distribution. DS Research. Retrieved from https://dailysocial.id/research

Fathurrohman, M. (2015). Model-Model Pembelajaran Inovatif. (N. Hidayah, Ed.). Jogjakarta: Ar-Ruzz Media. 
Fisher, A. (2007). Berpikir Kritis: Sebuah Pengantar. (G. Sagara, Ed.). Jakarta: Erlangga.

Li, \& Lam. (2013). Cooperative Learning. Hongkong Institute of Educatioin. Retrieved from www.ied.edu.hk/aclass

Nelson, L. P., \& Crow, M. L. (2014). Do ActiveLearning Strategies Improve Students ' Critical Thinking ? Higher Education Studies, 4(2), 77-90. https://doi.org/10.5539/hes.v4n2p77

Priyadi, R., Mustajab, A., Tatsar, M. Z., \& Kusairi, S. (2018). Analisis Kemampuan Berpikir Kritis Siswa SMA Kelas X MIPA dalam Pembelajaran Fisika. Jurnal Pendidikan Fisika, (April). https://doi.org/10.22487/j25805924.2018.v6.i1.100 20

Rachmawati, R. I. (2018). Pengaruh Penerapan Metode Problem Solving dan Metode Group Investigation Terhadap Kemampuan Berpikir Kritis Siswa dilihat dari Kemampuan Awal Pada awal tahun 2016 Masyarakat Ekonomi tinggi . Untuk dapat bersaing di MEA tentunya Indonesia harus menghadapi. Indonesian Journal of Economics Education, 1(1), 85-102. https://doi.org/10.17509/jurnal

Riandani, A. S. (2012). Penerapan Metode Problem Solving Sebagai Upaya Meningkatkan Kemampuan Berpikir Kritis Peserta Didik Kelas Viii A SMP Negeri 2 Kaloran Temanggung Dalam Mengikuti Mata Pelajaran IPS. Skripsi.

Rusman. (2010). Model-Model Pembelajaran: Mengembangkan Profesionalisme Guru (2nd ed.). Jakarta: PT Raja Grafindo Persada.

Slavin, R. E. (1995). Cooperative Learning (2nd ed.). USA: A Simon \& Schuster Company.

Sugiyono. (2010). Metode Penelitian Kuantitatif, Kualitatif dan R\&D. Bandung: Alfabeta.

Utami, B., Saputro, S., Ashadi, Masykuri, M., \& Sutanto, A. (2017). Implementation of Problem Solving With Concept Map to Improve Critical Thinking Skills and Chemistry Learning Achievement. International Conference on Teacher Training and Education 2017, 158, 153-162.

Wijayanti, W., Herlambang, S., \& Slamet, M. (2013). Pengaruh Model Pembelajaran Group Investigation (GI) Terhadap Kemampuan Berpikir Kritis Siswa Kelas X SMA Negeri 1 Mejayan Kabupaten Madiun. Jurnal Geografi. Retrieved from http://jurnal-

online.um.ac.id/data/artikel/artikel2405E92B2C971 A74C4C2BDB5B724F6E4.pdf

Yoke, S. K., Jangga, R., \& Kamal, S. N. M. (2015). Innovating with HOTS for the ESL Reading Class. English Language Teaching. https://doi.org/10.5539/elt.v8n8p10 